\title{
Combined pancreatic lipase-colipase deficiency
}

INSERM

\section{Source}

INSERM. (1999). Orphanet: an online rare disease and orphan drug data base. Combined pancreatic lipase-colipase deficiency. ORPHA:309111

Combined pancreatic lipase-colipase deficiency is a disorder of lipid absorption and transport characterized by steatorrhea with foul-smelling stools from birth, diminished serum carotene and vitamin E and a combined deficiency of the pancreatic enzymes lipase and colipase. Patients are otherwise healthy and develop normally with no apparent pancreatic disease. There have been no further descriptions in the literature since 1990. 